www.jmscr.igmpublication.org

Impact Factor 5.84

Index Copernicus Value: 71.58

ISSN (e)-2347-176x ISSN (p) 2455-0450

crossref DOI: _https://dx.doi.org/10.18535/jmscr/v5i11.77

\author{
Journal Of Medical Science And Clinical Research \\ IGM Publication \\ An official Publication of IGM Publication
}

\title{
A Study of Impact of Patient Education of Diabetes on His Knowledge, Attitude and Practices
}

\author{
Authors \\ Dr Sunita Gupta MD, Dr Mohit Singla MD, Dr Neeraj Gupta MBBS \\ Department of Medicine, Maharishi Markandeshwar Institute of Medical Sciences and Research Mullana, \\ Ambala, Haryana India \\ Corresponding Author \\ Dr Sunita Gupta \\ B2 Near Shiv Mandir, MMU campus Mullana Ambala India \\ Email: sanjeevguptadr@gmail.com, 91-9671023536
}

\begin{abstract}
Poor awareness among diabetic patients are some of the important variables influencing the progression of diabetes and its complications, which are largely preventable through education and involvement of the patient.

Objective: We evaluated the knowledge, attitude and practices in diabetic patients for diabetes mellitus and impact of the diabetic education on knowledge, attitude and practice(KAP) score.

Methods: The study was conducted among type 2 diabetic patients taken from O.P.D and indoor wards of M.M Institute of Medical Sciences and Research, Mullana, Ambala. A total of hundred diabetic patients were enrolled in the study and randomized into the test and control groups. Each group consisted of 50 patients. The patients in the test group received diabetic education and patient education leaflet at baseline and same was given to the control group at the end of the study. Knowledge, attitude and practices were evaluated using a KAP questionnaire with maximum score of 25(knowledge14, attitude-5 and practices-6)

Results: In our study population, 59(59\%) were males and 41(41\%) were females. Majority of patients (62\%) were between the ages 40-59 years and maximum number of patients (53\%) had diabetes less than 5years. Most of the patients (63\%)were overweight. The mean knowledge, attitude and practices score at baseline was 6.52(46.57\%), $2.26(45.2 \%)$ and $2.42(40.33 \%)$ respectively and mean KAP score was 11.21(44.84\%). At baseline, mean knowledge, mean attitude and mean practice score was $6.56 \pm 4.06,2.24 \pm 1.65$ and $1.74 \pm 1.26$ in the control group respectively and $6.48 \pm 4.49,2.18 \pm 1.36$ and $3.1 \pm 1.5$ in the test group respectively. Mean KAP score at baseline was $10.46 \pm 6.19$ in the control group and $11.96 \pm 6.84$ in the test group. At final follow-up, mean knowledge, mean attitude and mean practice score was $7.12 \pm 3.98,2.24 \pm 1.33$ and $1.92 \pm 1.34$ in the control group respectively and $12.12 \pm 2.12,4.12 \pm$ 0.87 and $4.46 \pm 1.01$ in the test group respectively. Mean KAP score at final follow up was $11.36 \pm 6.12$ in the control group and $20.78 \pm 3.13$ in the test group. At baseline, mean RBS was $228.58 \pm 83.58 \mathrm{mg} / \mathrm{dl}$ in the control group and $265.79 \pm 130.76 \mathrm{mg} / \mathrm{dl}$ in the test group, whereas at final follow-up mean RBS was $175.56 \pm 48.12 \mathrm{mg} / \mathrm{dl}$ and in the control group and $152.06 \pm 36.42 \mathrm{mg} / \mathrm{dl}$ in the test group. We observed significant increase in knowledge, attitude and practice score $(p<0.0001)$ and significant reduction in RBS $(p<0.0007)$ after education in the test group as compared to the control group.

Conclusion: The results of this study suggested that diabetic patients had low levels of knowledge, attitude and practice for diabetes mellitus. The health education is vital in improving patient's knowledge, attitude and practices regarding diabetes mellitus and attaining better glycemic control.
\end{abstract}




\section{Introduction}

Patient education plays an important role in effective management of chronic diseases such as Diabetes Mellitus. ${ }^{1}$ Patients if given proper education and guidance towards diabetes care would be able to make a significant improvement in life style which is helpful for good glycemic control. Education to diabetic patients would be more effective if we know the level of knowledge, attitude and practice of our patients. ${ }^{2}$ Education on disease, drugs, diet and life style modification can improve patient compliance to treatment recommendations and improves knowledge, attitudes and practices to enable patients to selfmanage the disease. ${ }^{1}$ Diabetes care includes knowledge in symptom recognition, diet and lifestyle modifications like routine exercise, adherence to medications, which includes dosage adjustment and timing, and detection and management of signs and symptoms of hyperglycemia and hypoglycaemia., ${ }^{3,4}$ Patients with diabetes mellitus often lack sufficient knowledge about their disease and thus frequently have poor self-management skills. ${ }^{5}$ So the present study is planned to evaluate the effect of diabetes education on glycemic control and improvement in knowledge, attitudes and practices regarding diabetes mellitus

\section{Materials and Methods}

The study was conducted at M.M. Institute Of Medical Sciences and Research, Mullana, Ambala. Total 100 adult target subjects of either sex were included in the study taken from OPD and Indoor Wards of Department of Medicine. Diagnosis of Diabetes was made as per American Diabetic Association (ADA) guidelines. ${ }^{6}$

Patient not fulfilling the definition of Diabetes Mellitus as per American Diabetic Association were excluded. Each subject underwent a detailed history elicitation including physical examination. A total of hundred diabetic patients were enrolled and randomized into the test and control groups. The patients in the test group received the education on their disease, drugs, diet and life style modifications and also Patient Education Leaflet $^{6,7}$ in Hindi to compliment the verbal counseling highlighting the disease, diet and life style modifications at the baseline and reinforcement of the same was done at the first follow-up. The control group patients had received education at the end of the study. After the baseline, two follow-ups were made at two months interval between the follow-ups. During each visit patient's plasma random blood glucose was measured by using a GOD-POD method. In case, the patient included in the study did not come for the first follow-up, then patient was approached for the same. A suitably designed and validated Knowledge, Attitude and Practice questionnaire (KAP Questionnaire) $)^{8,9,10}$ had been administered at baseline and final follow up for both test and control group patients to assess the disease management awareness. The KAP questionnaire had a total of 25 questions (Knowledge-14, Attitude-5 and Practice-6). Each 'Yes' answer was given a score of 'one' and 'No' answer was given a score of 'zero'. The questionnaire had been translated into Hindi. Patients taken for the study had been treated as per standard treatment schedule.

\section{Results}

We studied a total number of 100 patients of diabetes mellitus type2 at M.M. Institute of Medical Sciences and Research, Mullana, Ambala. Out of 100, they were randomly assigned to either test or control group. Each group consisted of 50 patients. The mean age was 48.96 years and standard deviation (SD) was 11.18 years. Out of 100 patients studied, 59 were males and 41 were females. In the study subjects more number of patients (53 i.e. 53\%) were having diabetes equal to or less than 5 years, followed by 28 patients $(28 \%)$ with the duration of $6-10$ years, 8 patients $(8 \%)$ with duration of $11-15$ years, 9 patients (9\%) with duration between 1620 years and only 2 patients $(2 \%)$ had diabetes for about 21-25 years. In this study 64 patients $(64 \%)$ were educated: 46 patients (46\%) up to school and 
18 patients $(18 \%)$ were graduated and 36 patients

$(36 \%)$ were illiterate.

Table 1: Comparison of Knowledge, Attitude, Practice, KAP Score and RBS between Control and Test Group

\begin{tabular}{|c|c|c|c|}
\hline Group & & Control & Test \\
\hline \multirow[b]{2}{*}{1} & $\begin{array}{c}\text { BASELINE KNOWLEDGE SCORE } \\
(\text { Mean } \pm \text { SD) }\end{array}$ & $6.56 \pm 4.06$ & $6.48 \pm 4.49$ \\
\hline & FINAL FOLLOW UP KNOWLEDGE SCORE $($ Mean \pm SD) & $7.12 \pm 3.98$ & $12.12 \pm 2.12$ \\
\hline \multirow[b]{2}{*}{2} & $\begin{array}{c}\text { BASELINE ATTITUDE SCORE } \\
(\text { Mean } \pm \text { SD })\end{array}$ & $2.24 \pm 1.65$ & $2.18 \pm 1.36$ \\
\hline & FINAL FOLLOW UP ATTITUDE SCORE $($ Mean \pm SD) & $2.24 \pm 1.33$ & $4.12 \pm 0.87$ \\
\hline \multirow[b]{2}{*}{3} & $\begin{array}{l}\text { BASELINE PRACTICE SCORE } \\
(\text { Mean } \pm \text { SD })\end{array}$ & $1.74 \pm 1.26$ & $3.1 \pm 1.5$ \\
\hline & FINAL FOLLOW UP PRACTICE SCORE(Mean \pm SD) & $1.92 \pm 1.34$ & $4.46 \pm 1.01$ \\
\hline \multirow[b]{2}{*}{4} & $\begin{array}{c}\text { BASELINE KAP SCORE } \\
(\text { Mean } \pm \text { SD })\end{array}$ & $10.46 \pm 6.19$ & $11.96 \pm 6.84$ \\
\hline & $\begin{array}{l}\text { FINAL FOLLOW UP KAP SCORE } \\
(\text { Mean } \pm \text { SD }\end{array}$ & $11.36 \pm 6.12$ & $20.78 \pm 3.13$ \\
\hline \multirow[b]{2}{*}{5} & $\begin{array}{c}\text { BASELINE RBS } \\
(\text { Mean } \pm \text { SD })\end{array}$ & $\begin{array}{c}228.58 \pm \\
83.58\end{array}$ & $265.79 \pm 130.76$ \\
\hline & $\begin{array}{l}\text { FINAL FOLLOW UP RBS } \\
(\text { Mean } \pm \text { SD })\end{array}$ & $\begin{array}{c}175.56 \pm \\
48.12\end{array}$ & $152.06 \pm 36.42$ \\
\hline
\end{tabular}

$\mathrm{p}<0.0001$

The table 1 shows that at baseline, the mean knowledge score was $6.56 \pm 4.06$ in the control group and $6.48 \pm 4.49$ in the test group, the mean attitude score was $2.24 \pm 1.65$ in the control group and $2.18 \pm 1.36$ in the test group, the mean practice score in the control group was $1.74 \pm 1.26$ and $3.1 \pm 1.5$ in the test group, the mean total KAP score was $10.46 \pm 6.19$ in the control group and $11.96 \pm 6.84$ in the test group. At final follow up, the mean knowledge score was $7.12 \pm 3.98$ in the control group and $12.12 \pm 2.12$ in the test group, the mean attitude score was $2.24 \pm 1.33$ in the control group and $4.12 \pm 0.87$ in the test group, the mean practice score was $1.92 \pm 1.34$ in the control group and $4.46 \pm 1.01$ in the test group, the mean total KAP score was $11.36 \pm 6.12$ in the control group and $20.78 \pm 3.13$ in the test group. Statistically, there was significant difference in knowledge, attitude, practices and total kAP score between the test and control group at final follow up with $\mathrm{p}$ value less than 0.0001 .

The mean RBS was $228.58 \pm 83.58 \mathrm{mg} / \mathrm{dl}$ in the control group and $265.79 \pm 130.76 \mathrm{mg} / \mathrm{dl}$ in the test group but at final follow-up the mean RBS was $175.56 \pm 48.12 \mathrm{mg} / \mathrm{dl}$ in the control group and $152.06 \pm 36.42 \mathrm{mg} / \mathrm{dl}$ in the test group. Statistically, there was significant difference in RBS between the test and control group at final follow up with $\mathrm{p}$ value equals to 0.0070 .

\section{Discussion}

The present study was aimed at evaluating knowledge, attitude and practices in diabetic patients for diabetes mellitus and to assess the benefitting effect of diabetic education on KAP score.

This study consisted of 100 type 2 diabetic patients which were randomly assigned into the test and control group. The test group patients were given education regarding disease, drugs, diet, exercise and the patient education leaflet at baseline and same was given to control group at the end of the study. In both the groups, at each visit (two follow up visits with two month intervals), random blood glucose was measured and a KAP questionnaire was administered at baseline and the final follow up with a maximum possible score of 25 (knowledge - 14, attitude - 5 and practices -6 ) The mean age was 48.96 years. 
This signifies that diabetes mellitus is more common after 45 years of age.In the study sbjects $59(59 \%)$ were males and $41(41 \%)$ were females. In our study, $54 \%$ patients were overweight, $9 \%$ patients were obese, $2 \%$ were underweight and remaining had normal BMI. The mean BMI was $26.5 \mathrm{~kg} / \mathrm{m}^{2}$. It shows that overweight patients are more prone to diabetes. Our findings were similar to previous studies. Kamal $\mathrm{M}$ Modhet $\mathrm{al}^{1}$ and Odenigbo Marian A et $\mathrm{al}^{11}$ found $53.33 \%$ and $57.5 \%$ overweight patients in their studies respectively.In the studied subjects $65 \%$ of the patients were having sedentary lifestyle (housewives- 35\% and service- 30\%). It shows DM is more common in sedentary lifestyle population Our findings were similar to the study done by Viral $\mathrm{N}$ Shah et $\mathrm{al}^{12}$ who found that maximum number of patients was housewives $(43.90 \%)$.

In the studied subjects, the mean knowledge, attitude and practice score at the baseline was 6.52 (46.57\%), 2.21 (45.2\%) and 2.42 (40.33\%) respectively. The mean KAP score at the baseline was $11.21(44.84 \%)$. The study observed poor knowledge score, attitude score and practice score of the patients The same results were observed in the previous studies. Odenigbo Marian A et al ${ }^{11}$ found poor knowledge (57\%), attitude $(56.6 \%)$ and practices $(51 \%)$ towards diabetes mellitus in the diabetic patients in Nigeria. Bhuwan Sharma et $\mathrm{al}^{13}$, Dinesh K Upadhyay et $\mathrm{al}^{14}$, Viral N. Shah et $\mathrm{al}^{12}$ and $\mathrm{F} \mathrm{H}$ Puepetet $\mathrm{al}^{15}$ observed poor levels of knowledge, attitude and practice in the studied subjects before education. Mumtaz Ali Chhuttoet $\mathrm{al}^{16}$ observed poor awareness in the diabetic patients for diabetes mellitus.

In our study, the mean knowledge score at baseline was 6.56 in the control group and 6.48 in the test group. At the end of the study, the mean knowledge score was 7.12 in the control group and 12.12 in the test group. There was significant improvement in the knowledge score in test group $(p<0.0001)$ at the end of the study as compared to the control group. This demonstrates that diabetes education plays a vital role in improving knowledge level of the patients. Our findings were similar to previous studies done by Bhuwan Sharma et $\mathrm{al}^{13}$, Titien Siwi Hartayu et $\mathrm{al}^{17}$, Subish

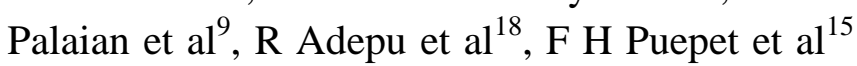
and Prianka Mukhopadhyay et $\mathrm{al}^{19}$ who found a significant increase in the knowledge level of the patients who were provided diabetic education..

The mean attitude score in the control group was 2.24 both at the baseline and final follow up. In the test group, the mean attitude score was 2.28 and 4.12 before and after education respectively. Thus, there was significant improvement in the attitude score in the test group $(\mathrm{p}<0.0001)$ while in the control group no improvement was observed. This signifies that diabetes education can improve patient's attitude towards diabetes mellitus. Our findings were similar to previous studies done by Bhuwan Sharma et $\mathrm{al}^{13}$, Titien Siwi Hartayu et $\mathrm{al}^{17}$, R Adepu et $\mathrm{al}^{18}$, F H Puepet et $\mathrm{al}^{15}$ and Prianka Mukhopadhyay et $\mathrm{al}^{19}$ who observed that diabetic education can improve patient's attitude towards diabetes mellitus.

In our study the mean practice score at baseline was 1.74 in the control group and 3.1 in the test group. At the end of the study, the mean practice score in the control group was 1.92 and in the test group was 4.46. This shows the significant improvement in the practice score in the test group $(\mathrm{p}<0.0001)$ as compared to the control group. This demonstrates that diabetes education can improve practices of the patients towards diabetes mellitus .Our findings were similar to previous studies. Bhuwan Sharma et $\mathrm{al}^{13}$, Titien Siwi Hartayu et $\mathrm{al}^{17}$, R Adepu et $\mathrm{al}^{18}$, F H Puepet et $\mathrm{al}^{15}$ and Prianka Mukhopadhyay et $\mathrm{al}^{19}$ found that health education plays a significant role in improving patient's practices towards diabetes mellitus.

The total KAP score observed in the control group was 10.46 at the baseline and 11.36 at the end of the study. In the test group, the total KAP score was 11.96 at the baseline and 20.78 at the end of the study. There was significant improvement in the total KAP score in the test group $(p<0.0001)$ as compared to the control group. This signifies 
that diabetes education plays a significant role in improving patient's knowledge, changing their attitude towards diabetes mellitus and self-care practices. Our findings were similar to previous studies. Bhuwan Sharma et $\mathrm{al}^{13}$ Titien Siwi Hartayu et $\mathrm{al}^{17}$ by $\mathrm{R}$ Adepuet $\mathrm{al}{ }^{18}$ by $\mathrm{F}$ H Puepetet al ${ }^{15}$ Mukhopadhyayet al ${ }^{19}$ by Subish Palaian et $\mathrm{al}^{9}$ concluded that health education plays a significant role in increasing KAP of the diabetic patients In the studied subjects, mean RBS at the baseline was $228.58 \mathrm{mg} / \mathrm{dl}$ in the control group and 265.79 $\mathrm{mg} / \mathrm{dl}$ in the test group. At the end of the study, the mean RBS was 175.56 in the control group and 152.06 in the test group. There was significant improvement in the RBS in the test group $(\mathrm{p}=0.0070)$ at the end of the study as compared to the control group. This demonstrates that diabetes education is important in reducing glucose levels and attaining better glycemic control. Our findings were similar to previous studies done by Mazzuca SA et $\mathrm{al}^{20}$, by Jaber LA et $\mathrm{al}^{21}$, by $\mathrm{F} \mathrm{H}$ Puepet et $\mathrm{al}^{15}$ and Mehuys $\mathrm{al}^{22}$ reported significant reduction in fasting plasma glucose and glycosylated hemoglobin in the patients who received diabetic education. Karter $\mathrm{AJ}$ et $\mathrm{al}^{23}$ found that selfmonitoring of blood glucose was associated with better glycemic control. So we concluded that the diabetic patients had low levels of knowledge, attitude and practices for diabetes mellitus. So, there is an urgent need for large scale health education programs to increase the awareness of diabetes mellitus in our population. The health education can improve patient's knowledge, attitude and practices in the diabetic patients for diabetes mellitus as there was significant improvement in the KAP score in the patients who were provided information leaflet. There was significant reduction in the RBS levels of the patients who were provided information leaflet. Thus, the health education is much effective in attaining better glycemic control and to adopt a healthy lifestyle. So, the physicians should also emphasize on patient's education along with management to attain good glycemic control.

\section{Bibliography}

1. Modh KM, Patel KM, Singh IA, Patel CN, Patel S. Impact of Clinical Pharmacist Intervention on Quality Of Life in Type 2 Diabetes Mellitus. Int J Adv Pharm Res. 2011 Aug;2(8):451-60.

2. Saadia Z, Rushdi S, Alsheha M, Saeed H, Rajab M. A study of knowledge, attitude and practices Of Saudi Women towards diabetes mellitus. A (KAP) study in AlQassim Region. The Internet Journal of Health. 2009;11(2).

3. Lewis RK, Lasack NL, Lambert BL, Connor SE. Patient counseling--a focus on maintenance therapy. Am J Health Syst Pharm. 1997 Sep 15;54(18):2084-98.

4. Renders CM, Valk GD, De Sonnaville JJ, Twisk J, Kreigsman DM, Heine RJ et al. Quality of care for patients with Type 2 diabetes mellitus--a long term comparison of two quality improvement programmes in Netherlands. Diabet Med. 2003 Oct;20(10):846-52.

5. Via PS, Salyer J. Psychosocial selfefficacy and personal characteristics of veterans attending a diabetes education program. Diabetes Educ. 1999 SepOct;25(5):727-37.

6. Executive Summary: Standards of Medical Care in Diabetes-2014. American Diabetes Association. Diabetes Care. 2014 Jan;37 Suppl 1:S5-13.

7. Park K. Nutrition and Health. In: Park K, editor. Park's textbook of Preventive and Social Medicine, 20thed.Jabalpur: BanarsidasBhanot;2009. p. 526-80.

8. Ng SH, Chan KH, Lian ZY, Chuah YH, Waseem An, Kadirvelu A. Reality vs Illusion: Knowledge, Attitude and Practice among Diabetic Patients. IJCRIMPH. 2012;4(5):723-32.

9. Palaian S, Acharya LD, MadhvaRao PG, Shankar PR, Nair NM, Nair NP. Knowledge, Attitude, and Practice Outcomes: Evaluating the Impact of 
Counseling in Hospitalized Diabetic Patients in India. PharmacolTher. 2006 Jul;31(7):383-95.

10. Malathy R, Narmadha MP, Ramesh S, Alvin JM, Dinesh BN. Effect of a diabetes counseling programme on knowledge, attitude and practice among diabetic patients in Erode district of South India. J Young Pharm. 2011 Jan-Mar;3(1):65-72.

11. Marian AO, Joy IO. Knowledge, Attitudes and Practices of People with Type 2 Diabetes Mellitus in a Tertiary Health Care Centre, Umuahia, Nigeria. J Diabetes Metab. 2012;3(3):187.

12. Shah VN, Kamdar PK, Shah N. Assessing the knowledge, attitudes and practice of type 2 diabetes among patients of Saurashtra region, Gujarat. Int $\mathbf{J}$ DiabDevCtries. 2009 Jul-Aug;29(3):11822

13. Sharma B, Mahajan H, Gill N. Impact of health education on knowledge, attitude, self care practices and life style modification factors in diabetic patients. International Journal of General Medicine and Pharmacy (IJGMP). 2013 Jul;2(3):2938.

14. Upadhyay DK, Palaian S, Shankar PR, Mishra P. Knowledge, attitude and practice about diabetes among diabetes patients in Western Nepal. Rawal Med J. 2008;33:8-11.

15. Puepet FH, Mijinyawa BB, Akogu I, AzaraI.Knowledge, Attitude and Practice of Patients with Diabetes Mellitus before and after Educational Intervention in Jos, Nigeria. The Journal of Medicine in the Tropics. 2007;9(1):3-10.

16. Chhutto MA, Qadr HUR, Abro HA, Shaikh MA, Shaikh BA, Shaikh N et al. Awareness of Diabetes Mellitus and its Complications in Diabetic Patients. Med Channel. 2009 Oct-Dec;15(4):153-6.
17. Hartayu TS, MI MI, Suryawati S. Improving of type 2 diabetic patients' knowledge, attitude and practice towards diabetes self-care by implementing Community-Based Interactive Approach Diabetes Mellitus Strategy. BMC Research Notes. 2012;5:315.

18. Adepu R, Rasheed A, Nagavi BG. Effect of patient counseling on quality of life in type-2 diabetes mellitus patients in two selected South Indian community pharmacies: A study. Indian J Pharma Sci. 2007;69(4):519-24

19. Mukhopadhyay P, Paul B, Das D, Sengupta N, Majumder R. Perceptions and Practices of type 2 diabetics: A crosssectional study in a tertiary care hospital in Kolkata. Int J DiabDevCtries. 2010 JulSep;30(3):143-9.

20. Mazzuca SA, Moorman NH, Wheeler ML, Norton JA, Fineberg NS, Vinicor F et al. The diabetes education study: a controlled trial of the effects of diabetes patient education. Diabetes Care. 1986 JanFeb;9(1):1-10.

21. Jaber LA, Halapy H, Fernet M, Tummalapalli S, Diwakaran H. Evaluation of a pharmaceutical care model on diabetes management. Ann Pharmacother.1996 Mar;30(3):238-43.

22. Mehuys E, De Bolle L, Van Bortel L, Annemans L, Van Tongelen I, RemonJPet al. Medication use and disease management of type 2 diabetes in Belgium. Pharm World Sci. 2008 Jan;30(1):51-6.

23. Karter AJ, Ackerson LM, Darbinian JA, D'Agostino RB Jr, Ferrara A, Liu Jet al. Self-monitoring of blood glucose levels and glycemic control: the Northern California Kaiser Permanente Diabetes registry. Am J Med. 2001 Jul;111(1):1-9. 